\title{
Review
}

\section{Biodiversity conservation of coastal fish of Indonesia}

\author{
[Konservasi keanekaragaman hayati ikan pantai di Indonesia] \\ Victor PH Nikijuluw \\ Conservation International (CI), Indonesia
}

Received: 25 July 2018; Accepted: 9 October 2018

\begin{abstract}
Each species has a special value. No species was created without intention. If one species matters, all species are altogether admirably important. This paper elucidates critical importance of species conservation in the context marine fish biodiversity in Indonesia. This resource endowment has not been truly known and hence improperly utilized. As direct consequences, biodiversity loss and species extinction are unstoppable trend. This condition is attributed to the lack systematic research and serious education programs. Beside the needs of improving research and education at national level, conservation programs should be intentionally adapted by regional government. Of the various available conservation approaches, the adapting of focal species by each regional government may become an effective approach to massively promote fish conservation program at provincial and regency levels. It also may become an input for conservation practices at larger scale.
\end{abstract}

Keywords: biodiversity loss, capacity building, focal species, regional government, species conservation

\begin{abstract}
Abstrak
Setiap spesies mempunyai nilai khusus. Tidak ada satu spesies pun yang diciptakan tanpa tujuan. Jika satu spesies saja begitu berarti, keberadaan semua spesies sekaligus sangat penting. Makalah ini menekankan begitu pentingnya konservasi spesies pada keragaman hayati laut di Indonesia. Sumber daya ini belum diketahui dengan sempurna dan sebab itu menjadi alasan untuk tidak dimanfaatkan dengan baik. Sebagai akibatnya, kehilangan keragaman hayati dan kepunahan spesies adalah kecenderungan yang tidak terhentikan. Hal ini terjadi karena kekurangan penelitian dan program pendididikan. Selain kebutuhan untuk meningkatkan penelitian dan pendidikan pada skala nasional, program konservasi harus sengaja diadakan di tingkat daerah. Dari berbagai pendekatan program konservasi, penentuan spesies kunci bisa menjadi pendekatan efektif untuk mempromosikan konservasi spesies ikan secara masif oleh pemerintah daerah provinsi atau kabupaten. Pendekatan ini bisa menjadi pelajaran bagi praktif konservasi pada skala yang lebih luas.
\end{abstract}

Kata penting: keanekaragaman hilang, pembentukan kapasitas, pemerintah regional, spesies kunci, konservasi spesies

\section{Introduction}

The two keywords of this article are biodiversity and conservation. There is a close interrelatedness or correlation between the words. Biodiversity will be assuredly and perpetually in place if there are proper conservation programs. On the other hand, effective conservation programs should be provoked and engendered by biodiversity. Without or with less degree of biodiversity, conservation of particular place, habitat, or ecosystem is seemingly exaggerated. Con

$\triangle$ Correspondence author

E-mail address: vnikijuluw@conservation.org servation programs can be designed to specifically protect certain species or a group of species. Nevertheless, protecting and sustaining biodiversity should be the main reason to have a high value conservation programs.

In this paper, biodiversity, a contraction of biological diversity, is defined in accordance with UN Convention on Biological Diversity (UNCBD) as "the variability among living organisms from all sources including, inter alia, terrestrial, marine and other aquatic ecosystems and the ecological complexes of which they are part; this includes diversity within species, be- 
tween species and of ecosystems" (SCBC 2010). Hence, biodiversity of marine fish may be defined simply as variability and richness of fish species in marine ecosystem as their habitat.

What is conservation? In biological and ecological sciences, conservation may defined as the management of nature and of earth's of biodiversity with the aim of protecting species, their habitats, and ecosystems from excessive rates of extinction and the erosion of biotic interactions (Soule 1986). It is an interdisciplinary subject drawing on natural and social sciences, and the practice of natural resource management.

A more practical definition of biological conservation is stated in Business Dictionary as usage, improvement, and protection of human and natural resources in a wise manner, ensuring derivation of their highest economic and social benefits on a continuing or long-term basis. It is achieved through alternative technologies, recycling, and reduction in waste and spoilage and (unlike preservation) implies consumption of conserved resources. This definition emphasizes sustainability use of the resources and how they are optimally utilized and economically impactful to mankind.

A formal definition of conservation according to the Law No: 5/1990 is as the following. "Conservation of natural resource is a natural resource management whose utilization is wisely conducted by ensuring its sustainability, maintaining its diversity, and improving its value. Conservation is undertaken by three substantial elements; protection of life support system, preservation of biodiversity and ecosystem, and sustainable utilization of natural resources and ecosystem (Article 5, Law No: 5/1990). By the Law No 31/2004 on Fisheries, conservation refers to all efforts of protecting, preserving, and utilization of fisheries resources, including the ecosystem, species, and genetics to ensure the availability and sustainability of fish stocks, by preserving and improving the quality of fisheries resources.

Coining the words together, biodiversity conservation may be defined as protection, preservation, and sustainable use of variety and richness of species (or group of species) in the wisest manner and for optimal benefit to people so that the species and their habitat quality will not be degraded but sustained in the long-run.

This article focuses on the present state, threats, and strategic policies of fish conservation in Indonesia. It begins with discussion on the reasons and spectrum for species conservation. It also elaborates number of species and their diversity and concludes with addressing of action programs that include research and education aspects.

\section{Species conservation}

Every fish species is important and entails specific value either to nature or human. Ecological, biological, and social economic functions of many species have been successfully identified and recognized. Yet there are many more species whose existence has not been unidentified and understood yet. Some species at the bottom of the sea may have not been invented even, given our current exploration technologies, sciences, and knowledge. Nonetheless we cannot jump into conclusion that those that have not been scientifically studied and identified are unimportant for us and nature. It is a true that every creature has a specific value, purposefully created by God. This is basically the principle of conserving species diversity.

Every species has a meaning. Hence all species altogether even have a magnificent meaning. They are depending, influencing, supporting, 
or competing one to another in their habitat. Therefore, their coexistence constructs their life. Their diversity sustains their life. Scientists have long determined species diversity as one of crucial elements of biodiversity.

Based on this way of thinking, I have courage to propose basic laws of species conservation that can be simply propounded as follow:

Law number-1: Every species is created for a purpose.

Law number-2: Unidentified and unknown species are also created for a reason.

Law number-3: Species are altogether constructing and uphold their life.

There are three levels of biodiversity: (1) genetic diversity - the variety of genetic information contained in individual plants, animals and micro-organisms, (2) species diversity - the variety of species, and (3) ecosystem diversity the variety of habitats, ecological communities and ecological process. Based on biodiversity hierarchy and level of biological complexity, Peck (1998) classified 12 types of marine biodiversity, of which fish species diversity seems to be the most significant one (Figure 1). Without species as a living component, habitat and seascape will not be that meaningful. In the same vain, genetic diversity can only be distinguished if it is within and among species. Conserving species diversity is therefore exceedingly important to safeguard the biological life support systems. A place functions as a habitat if living organisms or species are there. A question that needs to be raised is: are all species equally important for conservation purposes? The answer is that all species are important and must be conserved. None of them should be permitted to become extinct. Species that are considered not economically important today may be highly appraised in the future. Species that are biologically proved irrelevant for human today may be found more significant tomorrow.

Do some species play more significant roles than others in the structuring or functioning of their habitat and providing goods and services to human? Answer of this question will be a basis for strategic and effective conservation programs.

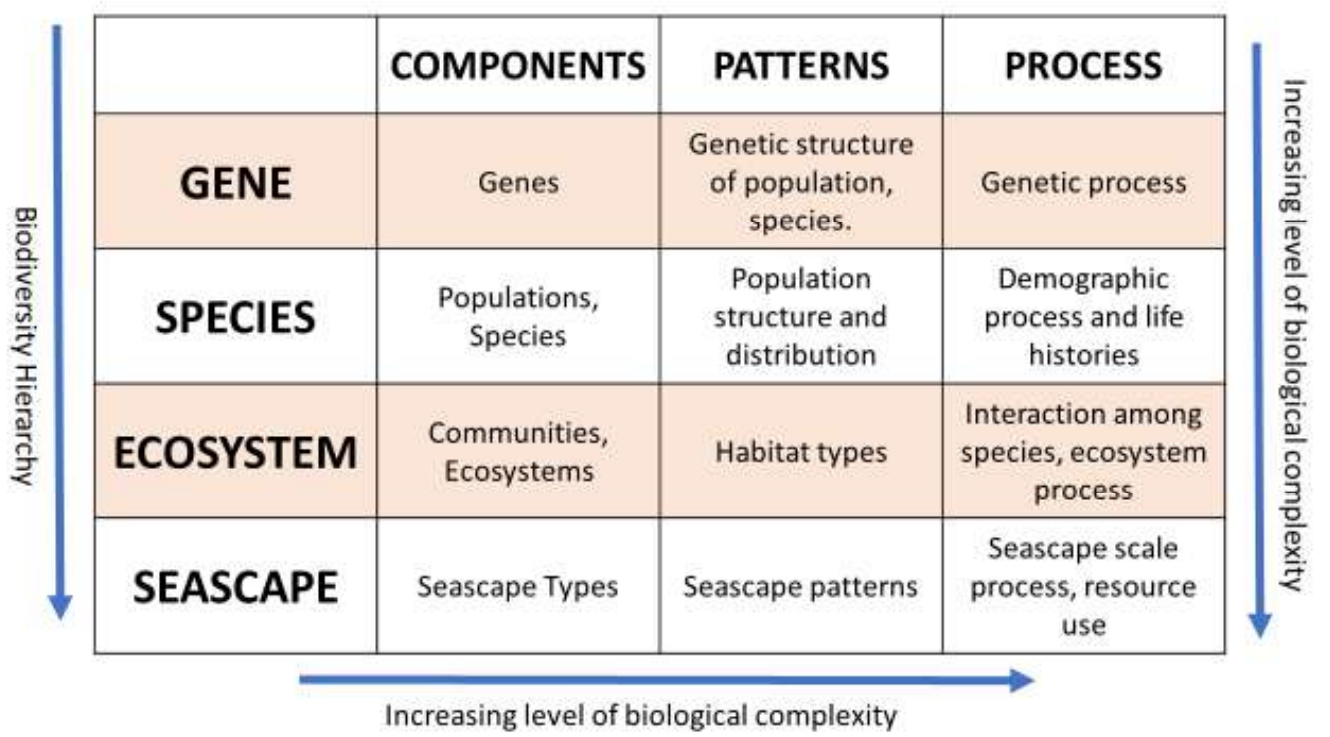

Figure 1. The biodiversity hierarchy (adapted from Peck 1998) 
Roff and Taylor (2000) argued that conservation activity seems to have swung away from individual species and toward emphasis on the habitats and spaces. Nevertheless, they suggested to pay preferential attention to conserve so-called focal species that are those, which for ecological and social reasons, are believed to be valuable for the understanding, management, and conservation of natural environments. Managing or conserving the focal species will consequently lead to the management of habitats or ecosystems.

Many scientists have proposed different ways of defining and categorizing focal species. According to Roff and Zacharias (2011), focal species may comprise (1) indicator species, (2) keystone species, (3) umbrella species, and (4) flagship species. They are shortly elaborated in the next paragraphs:

1. Indicator species are those whose presence or absence denote the condition or health of a particular habitat, community, or ecosystem.

Manta rays, especially the larger species or oceanic manta, Manta birostris, and the smaller species or coastal manta, Manta alfredi, may be considered as indicator species as they live in the waters rich in zooplankton and small fish. The rich ecosystem of Raja Ampat waters are apparently found to be nursery grounds for manta as many small size individuals are present in the areas. Large size individuals occur also in Raja Ampat waters that indicate the environment are in a healthy condition. Therefore manta is an indicator species for Raja Ampat ecosystem.

2. Keystone species are those entailing critical ecological function of a community or habitat and exerting a disproportionate influence on community structure relative to its abundance or biomass.

Yellowfin tuna are found to a keystone species with regard to spotted dolphin (Stenella attenuata), to a lesser extent with spinner dolphin ( $S$. longirostris), and common dolphin (Delphinus delphis). The basis of their association is partly due to shared or preferred food source. Interaction possibilities between tuna and dolphin include competition, parasitism, and commensalism. Reduced number of yellowfin tuna significantly affects presence of dolphins (Wild 1994).

Another example of keystone species is southern bluefin tuna (SBT). Studies showed that juveniles and adults are opportunistic feeders chiefly on cephalopods, crustacean, fish, and saps. In general, smaller SBT feed mainly on crustacean. Increased numbers of SBT landings influence other species, especially crustaceans (Caton 1994).

Group of demersal species in Java Sea can be considered as keystone species. High exploitation of the species by trawlers and the similar gears detrimentally affected their stocks, significantly reduced their landings, but consequently increased abundance of jelly fishes that might be considered as target preys. The sudden appearance of jelly fish in previously demersal species dominated waters are normally termed as an ecosystem overfishing (Nikijuluw et al. 2007).

Predatory starfish (Pisaster ochraceus) is also a keystone species as its presence kills corals and mussels. This predatory starfish feeds on the mussel, Mytilus californianus, and is responsible for maintaining much of the local diversity of species within certain communities. When the starfish have been removed experimentally, the mussel popula- 
tions have expanded rapidly and covered the rocky intertidal shores so exclusively that other species cannot establish themselves. Consequently, the interaction between Pisaster and Mytilus supports the structure and species diversity of these communities. In other communities in which Pisaster occurs, however, the starfish has little overall effect on the structure of the community. Therefore, a species can be a keystone species in some communities but not in others. Increased number of the starfish in a habitat could kill coral ecosystem. Yet its existence could potentially create balance of ecosystem as the species eat other predators whose presence may dominate the ecosystem.

3. Umbrella species are the ones whose presence in a geographical area indicates that other species will also be present. Conservation of the umbrella species will also protect other species. The species normally demonstrate stubborn fidelity to particular habitats. Ocean sunfish (Mola ramsayi) can be included in this species category. The fish is found to continually live in Nusa Penida and Nusa Lembongan waters and drawing special attention of tourists. This ecoparasite laden fish is found to be cleaned by smaller reef fishes (Thys et al. 2016). Having a mutualism relationship, conservation of ocean sunfish in its habitat obviously will protect other fish. Some local fishers testified to see ocean fish at Flores and Timor islands.

Rastrelliger kanagurta (Indian mackerel) may be also considered as an umbrella species in the Mayalibit Bay, Raja Ampat, West Papua. The almost-perfectly-closed bay is the habitat for the species caught by smallscale traditional fishers. Besides, there are sedentary species mainly sea cucumber and other small pelagic fishes found in the bay. An attempt has been addressed to traditionally manage the bay with Indian mackerel as the main target. Resource management mechanisms of opening and closing fishing seasons coupled with gear restriction are applied to conserve the fish. This resource management measures undoubtedly also protects ecosystem and other organisms.

4. Flagship species usually garner public support to conserve the species and their habitat. They can be non-migratory or migratory species and appropriately managed by traditional or indigenous management approaches.

Whale shark (Rhincodon typus) may be considered as the flagship species in Raja Ampat and Kaimana waters. The species occurs intensively in Cendrawasih Bay. Manta ray and other whales may be considered also as flagship species for the habitat and areas where they live or migrate. Conservation of flagship species is normally gaining attention from both local and international communities. Their conservation, therefore, may become an effective strategy in in protecting ecosystem and promoting regional development especially trough tourism sector.

Tuna (family Scombridae), especially skipjack (Katsuwonus pelamis), yellowfin (Thunnus albacores), bigeye (Thunnus obesus), and albacore (Thunnus alalunga) are commercially flagship species that have been heavily exploited in Indonesian waters and therefore are in earnest alarms to be conserved. Regrettably, their high global market demand encourages fishing industries to hunt after the species and contrariwise makes the authorities reluctantly con- 
serve them or apply sustainable management measures.

Beside the above species categories, locally endemic and socially charismatic species are gaining popularity as reasons for conservation. Conservation of endemic species prevents the species from extinction and extirpation. Conservation of socially charismatic species will not only protect the species and their habitats but also uphold values and beliefs of the local adherents who advocate and support the conservation.

Of the nine walking (bamboo) sharks (Hemiscyllium) species that have been found in the world, six have been proved endemism in Papua and Mollucas. The six species are H. freycineti (Raja Ampat Islands); H. galei (Cenderawasih Bay); H. halmahera (Halmahera, Indonesia); H. henryi (vicinity of Triton Bay, Kaimana); H. strahani (vicinity of Jayapura), and H. trispeculare (northwestern Australia and Aru Islands). Locally by Papuan, the species are named "Kalabia", meaning walking sharks. They have been systematically used to promote conservation of coral reefs and coastal ecosystem where they live. A floating education on conservation program by the name of "Kalabia" was established by a local NGO whose main program is to educate and train children on conservation. University of Papua (UNIPA) and University of Pattimura (UNPATTI) are conducting researches to determine right management mechanism to conserve the species as parts of sustainable coastal management.

Charismatic species, often conceived as flagship species, are inherently and traditionally regarded and respected by local peoples. Dugongs and sharks are so loftily esteemed by many villagers of Mollucas that they are not caught for consumption. Whale sharks are so highly honored as the King of Fish that they are not killed although unwittingly caught by light lift-netters at Kaimana, Raja Ampat, and Cendrawasih Bay. The species are treated charismatically by local peoples. They can be easily adapted to become target of conservation program.

\section{Richness of Indonesian Fish}

About $34 \%$ of the world's fish species, about 8,500 species, occur in Indonesian waters (Persoon \& van Weerd 2016). About 108 species $(0.4 \%$ of the global) are endemic and 95 species (1.1\% of the global) are seriously threatened. According to Gray (1997), the highest species diversity in the world occurs in the Indonesian archipelago and decreases radially from there.

Allen \& Erdmann (2012) reported that Indonesia has highest diversity reef fish hotspots compared to other location in the region. Using number of species recorded and the Coral Fish Diversity Index (CFDI), they predicted number of reef fish species at 10 locations in Indonesia. The prediction result is presented in Table 1. They also identified number of endemic species occurred in selected waters of Indonesia that in fact more than number of endemism found in the neighboring countries (Table 2). In total, there are 152 endemic reef fishes in selected areas of Lesser Sunda Islands, North Sulawesi, and West Papua. Surveys are needed to find and disclose richness of reef fish biodiversity at other locations in Indonesia.

About 600 reef species occur in the Pulau Weh and northern tip of Sumatra. Another survey carried out in Bintan dan Riau Archipelago in 1997 discovered an impoverished reef-fish of only 315 species. There were no comprehensive surveys for the Java region, although it was estimated a total 500-600 species in Seribu Island, Northern Jakarta. The waters of Berau region in East Kalimantan are inhabited by 900 species. 
Table 1. Coral fishes diversity at selected locations in Indonesia

\begin{tabular}{clccc}
\hline No & \multicolumn{1}{c}{ Locality } & \# of species recorded & $\begin{array}{c}\text { Coral Fish Diversity } \\
\text { Index }\end{array}$ & $\begin{array}{c}\text { Predicted \# of spe- } \\
\text { cies }\end{array}$ \\
\hline 1 & Raja Ampat & 1347 & 373 & 1465 \\
2 & Maumere Bay & 1111 & 333 & 1108 \\
3 & Triton Bay, Kaimana & 1005 & 322 & 1249 \\
4 & Halmahera & 974 & 327 & 1271 \\
5 & Bali and Nusa Penida & 977 & 337 & 1372 \\
6 & Cendrawasih Bay & 965 & 302 & 1165 \\
7 & Berau & 875 & 316 & 1050 \\
8 & Komodo Island & 750 & 280 & 928 \\
9 & Pulau Weh & 533 & 196 & 644 \\
10 & Bintan Island & 304 & 97 & 308 \\
\hline
\end{tabular}

Adapted from Allen \& Erdmann (2012)

Table 2. Reef fish endemism for Indonesia

\begin{tabular}{cccc}
\hline Region & \# of endemic species & Region & \# of endemic species \\
\hline Lesser Sunda Island & 52 & West Papua & 42 \\
Bali to Komodo & 25 & Cendrawasih Bay & 15 \\
Flores to Alor & 15 & Raja Ampat & 13 \\
& & Triton Bay & 6 \\
North Sulawesi & 14 & & 159 \\
Tomini Bay & 8 & INDONESIA & \\
\hline
\end{tabular}

Adapted from Allen and Erdmann (2012)

Remarks: Categories are not mutually exclusive. Raja Ampat endemic would also be endemic to West Papua and to Indonesia

The Berau region is possibly the richest marine fauna in the Greater Sunda Islands (Sumatra, Java, and Kalimantan).

There were about 1,000 coral fish species found in Nusa Penida, Bali. A slightly over 1,100 species were found in Maumere Bay, Flores. A survey at the Banggai and Togean Islands, Central Sulawesi, in 1988 documented 820 species. Approximately, 1,200 and 1,000 species were found in Aru and Halmahera waters, respectively.

The waters of West Papua Province where Bird's Head Seascape (BHS) is located is possibly the richest and most biodiversity region in Indonesia and even in the world. More than 1,638 coral-associated fish were documented in the BHS. Several surveys done in the BHS at the course of 1998 to 2015 indicated 1,437 species for Raja Ampat Islands, 1,005 species for the Fak-Fak and Kaimana, and 965 species for Cendrawasih Bay (Allen \& Erdmann 2012). Comparing the richness reef fish at the BHS with those of CTI countries and the eastern Indian Ocean, one could say that the BHS is the epicenter or the hotspot of marine biodiversity.

Endowed with richness of marine fish, it does not necessarily mean that are commercially utilized. In some regions, coral reefs and their associated fishes have been developed as tourism objects that require conservation management for their sustainability. Conservation programs at selected coral reef ecosystems and regions of Indonesia have been effectively conducted.

Less number of species is caught for commercial reason. By the Maximum Sustainable Yield (MSY) estimate, they are categorized 
into eight species groups: large pelagic fishes (including big tuna), little tunas, shrimps, demersal fishes, small-pelagic fishes, coral fishes, lobsters, and squids. Nevertheless, the Statistics of Indonesian Capture Fisheries which is mainly based on the landing reports at fishing ports and auction markets has recorded the catch only by 191 species of finfishes, 11 species of crustaceans, 11 species of mollusks, and 4 species of aquatic animals. In total, 216 species are only recorded by this annual statistics. The fisheries statistics has successfully reflected biodiversity of economically important species. Yet, unidentified catch, not recorded in the statistics can be used to determine species that should be protected, conserved, and unallowably or limitedly fished.

\section{Threats of biodiversity loss}

Biodiversity is not static. It is constantly changing. It can be increased by genetic change and evolutionary processes. It also can be reduced by threats which lead to population decline and extinction.

Increased number of the CITESAppendix-listed and IUCN-red listed species are true signals of biodiversity loss. Attempts to prevent further loss are generally lacking and ending at scientific papers and discussion forums. Public agencies normally do not pay significant attention and commitment on biodiversity-losspreventing programs. Conversely, many development programs in fact tend to accelerate exploitation and increase commercial utilization rates. Due to lack of information and scientific research and monitoring, loss of species in marine ecosystem is not easily detected. However, almost all marine mega faunas have been included as critically endangered (CR), endangered (EN), and vulnerable (VU) species into the IUCN red list. Increased number of species have been listed in the CITES appendices I, II and III.

Miller (2005) proposed the following reasons for the unstoppable trend of biodiversity loss:

(1) Assumption that an "educate-the-public" approach will be sufficient to motivate change. This implies that education is necessary but not sufficient. It should be followed by real action conservation programs that involved those who have been trained and educated.

(2) Estrangement of people from nature. People become less sensitive to natural phenomena since they are driven away from direct contact with nature. Consequently, they tend to disregard important undesirable natural incidences such as decreased population and finally species extinction.

(3) Collective ignorance that might be attributable to absence of guiding policies and real example.

Hutomo \& Moosa (2005) revealed causes or problems of biodiversity loss in Indonesian coastal and marine ecosystem. They suggested ensuing aspects that are continually threatening existence of biodiversity:

1) Rapid population growth and stubborn poverty in coastal areas.

2) Lack of policy implementation and poor law enforcement.

3) Lack of awareness on the strategic importance of coastal and marine resources.

4) Lack of political will to apply sustainable development principles.

5) Lack of recognition of local tradition, rights, indigenous knowledge, and communitybased participation. 
6) Unawareness on the importance of an integrated approach in coastal and marine development.

7) Lack of capable human resources.

8) Lack of information as a basis for rational an optimal use of marine resources and poor existing system to access available information.

Other variables that contribute to biodiversity degradation are introduction of species that are invasive in nature, impact of global climate change and sea level rise, and changes in regional political regimes that eventually affect local policies in natural resource utilization and management. Implementation of Law 23/2014, for instance, when authority of coastal area and fisheries resource management is upwardly shifted from regency to provincial government has brought about unexpected consequences of losing incentives, interests, and responsibilities of regency's government in undertaking species and habitat conservation programs.

A major impediment to reducing biodiversity loss is our limited knowledge of the true extent of biodiversity, its evolutionary history, and the forces that shape responses to environmental change. We are thus currently underprepared to recognize contemporary changes and to implement appropriate responses. Although much fundamental work remains to be done, the information currently available already allows some inferences and predictions about the future. It also allows us to formulate broad areas of evolutionary investigation that are of direct relevance to the discovery, documentation, sustainable use, and protection of biodiversity.

\section{Conservation strategies}

The first and foremost strategy of species conservation is availability of national policy that provides legal foundation for action programs and projects. Protocol of species conservation should be developed for each targeted species. Good governance at the national, provincial, and local levels that cover human resources, planning, and program implementation should be developed and committed to be executed. Interagencies collaboration and involvement of stakeholders, including national and international NGOs, should be hammered out. The collaboration can be directed to execute multiyear conservation activities that are unmanageably executed by using government budgets.

Capacity buildings of institutions and government personnel are the next in importance and therefore should be prioritized. Conservation offices and sections at central government and local government agencies should be developed and empowered to provide better capacity on which sound and effective conservation programs can be designed and implemented. Training and education of government officials should be programmed in the aspects of conservation science, technology, and management.

Indonesia is lacking in conservation knowledge. Only few institutions doing continues researches that provide results applicable in policy formulation. In similar way, not so many universities are offering special programs or subjects that are related to conservation. There are many impediments indeed to establish and maintain ideal research and training institutions. Nonetheless, the capacity development in the conservation knowledge and science should not be halted and forsaken. It should be prioritized and persistently improved.

Under the existing circumstances of lacking in policy, program, and capacity, various insitu species conservation programs have been designed and implemented. The National Plan of 
Action (NPOA) for several species such as napoleon fish (Cheillinus undulatus), seahorse (Hyppocampus spp.), trochus (Trochus niloticus), sea cucumber (Holothruroidea), giant clam (Tridacna gigas), and various species of sea turtles have been enacted and ready to implement. Marine mega faunas especially whale-shark have been effectively protected. The government is enlarging conservation horizon to also cover other species of sharks and rays and in the preparation of inclusion the species into the CITES appendixes. The above mentioned government efforts have brought about positive influence on species conservation.

Another significant strategy that has been taken by the government is area conservation program that automatically will conserve species that are partly or entirely living in the area. The central government has globally committed and proclaimed to establish 20 million hectares of marine protected areas (MPAs) that will be achieved by 2020 . In the process to fulfill the commitment, some MPAs have been effectively managed and provided mechanism for species conservation. The 4.3 million hectares of BHS MPAs, for instance, have been able to protect whale shark, walking shark, manta rays, dugongs, sunfish, and multifarious coral fishes. Sustainable fisheries management schemes for artisanal and commercial purposes have been designed and begun to implement. A customarybased fishery has been revitalized as a management scheme within MPAs.

MPAs also triumphantly prevent different commercial fish such as tunas, skipjack, scads, mackerels, sharks, groupers, and snappers from uncontrollable and unmanageable commercial fishing. This impactful result shows the importance of managing habitat or ecosystem.
Maduppa et al. (2013) in their study revealed the importance of managing habitat to protect species. Considering ecological network, conserving habitat and species altogether is a powerful strategy (Graham 2004). Conserving habitat will result in increased fish abundances and species that are target of fisheries respond particularly well to protection (Mosquera et al. 2000).

\section{Concluding remarks}

Indonesia is endowed with huge fish biodiversity resources. Many species have been successfully and scientifically identified. Yet there might be many more have not been studied and taxonomized. Likewise, only small percent-tage of the species that have been recognized to have economic and social values.

We have committed to have conservation programs at national and local government levels. However, the programs seem not to be able to cease or prevent from increasing biodiversity loss and degradation. The very basic reason of this is the fact that we have very limited knowledge on species living in our waters. Research, education, and awareness campaign on this aspect are indeed very short in number. As consequence, we tend not to pay special homage and respect to the need of species conservation in order that they can exist and provide everlasting benefits.

There are many ways, approaches and methods to bring every single species under conservation program since each species is purposefully created. Yet the main pillars for species conservation are research and education. There are plenty room of opportunities for research and education on species conservation in Indonesia. Every research institution and university in the 
country should deliberately design their programs by which conservation should be included. Government should widely open their arms to invite local and international NGOs to work on conservation programs. Huge obstacles such as multi-years funding, qualified staffs, and supporting international works that may encountered by the government could be handled and overcome by collaborating with private sectors and NGOs.

Species conservation and management will be more effective if the species are specially destined and loftily esteemed. Under political circumstances where every regency and province are promoting their regions on sustainable development, it would be a very strategic conservation approach if each government could determine its specific flagship species and use it as a mascot of economic development and investment promotion program. If each of about 400 coastal regencies could determine and proclaim one flagship species for their respective region, there would be about the same number of species that are highly esteemed and wittingly conserved. Using flagship species as a regional mascot that is based on research, tradition, and its relative importance for local people, conservation programs of the species could be further developed that finally may provide long-term benefits to the government and communities.

\section{Reference}

Allen GR, Erdmann MV. 2012. Reef Fishes of the East Indies, Volume I-III. Tropical Reef Research. Perth, Australia.

Caton AE. 1994. Review of aspects of southern bluefin tuna biology, population, and fisheries, p. 296-343 In: Shomura RS, Majkowski J, Langi S. (Eds). Interactions of the Pacific Tuna Fisheries. Proceedings of the First FAO Expert Consultation on Interaction of Pacific Tuna Fisheries. 3-11 December 1991. Noumea, New Caledo- nia. Volume 2: papers on biology and fisheries. FAO Fisheries Technical Paper, No. 336, Vol. 2. FAO Rome, 1993. 439 p.

Graham B. 2004. Integrating Biodiversity Conservation and Sustainable Use: Lessons Learned from Ecological Networks. IUCN, Gland, Switzerland, and Cambridge, UK. vi +55 pp.

Gray J. 1997. Marine biodiversity: patterns, threats and conservation needs. Biodiversity and Conservation, 6(1): 153175.

Hutomo M, Moosa MK. 2005. Indonesian marine and coastal biodiversity: Present status. Indian Journal of Marine Science, 34(1): 88-97.

Maduppa HH, Agus SM, Farhan AR, Suhendar D, Subhan B. 2012. Fish biodiversity in coral reefs and lagoon at the Maratua Island, East Kalimantan. Biodiversitas, 13(3): 145-150.

Miller JR. 2005. Biodiversity conservation and the extinction of experience. Trends in Ecology and Evolution, 20(8): 430-434.

Mosquera I. Côté IM, Jennings S, Reynolds JD. 2000. Conservation benefits of marine reserves for fish populations. Animal Conservation, 4: 321-332.

Nikijuluw VPH, Poeloe J, Dahlan MN, Purba CB. 2007. Sistem Alternatif Manajemen Sumberdaya Kelautan dan Perikanan. Pusat Riset Perikanan Tangkap. Departemen Kelautan dan Perikanan. 178 p.

Peck S. 1998. Planning for Biodiversity: Issues and Examples. Island Press, Washington DC.

Persoon GA, van Weerd M. 2016. Biodiversity and natural resource management in insular Southeast Asia. Island Studies Journal, 1(1): 81-108.

Roff, J.C. and Taylor, M. 2000. A geophysical clasification system for marine conservation. Journal of Aquatic Conservation: Marine and Freshwater Ecosystem, 10:209-223

SCBC (Secretariat of the Convention on Biological Diversity). 2010. Global Biodiversity Outlook 3. Montréal, Canada.

Soule ME. 1986. What is conservation biology? BioScience, 35(11): 727-734. 
Thys T, Ryan JP, Weng KC, Erdmann M, Trestani J. 2016. Research Article. Tracking a marine ecotourism star: Movements of the short ocean sunfish (Mola ramsayi) in Nusa Penida, Bali, Indonesia. Journal of Marine Biology, 26: 1-6.

Wild A. 1993. A review of the biology and fisheries for yellowfin tuna (Thunnus albacares) in th Eastern Pacific Ocean. p. 52-107 In: Shomura RS, Majkowski J, Langi S. (Eds). Interactions of the Pacific Tuna Fisheries. Proceedings of the First FAO Expert Consultation on Interaction of Pacific Tuna Fisheries. 3-11 December 1991. Noumea, New Caledonia. Volume 2: papers on biology and fisheries. FAO Fisheries Technical Paper, No. 336, Vol.2. Rome, FAO. 1993. 439 p. 